\title{
THE MATERIAL WORLD OF THE EARLY TWENTIETH-CENTURY REINDEER BREEDING OROCHONS OF TTANSBAIKAL IN THE DIMENSION OF CULTURE
}

Keywords: material world, ethnocultural specificities, traditional ethnographic complex, Orochons, Russian Ethnographic Museum collections, 1927-1928 Tunguska expedition, mentality.

\begin{abstract}
The article makes the first comprehensive attempt at examining the material world of the early twentieth-century reindeer breeding Orochons of Transbaikal, drawing on a broad range of materials from the Russian Ethnographic Museum and applying systems analysis and hermeneutic methods to interpret results. The study employed a comparison and juxtaposition of the material culture of the Orochon to that of the neighboring Evenks and ethnic groups of the Lower Amur, as well as other peoples of Central and Eastern Asia. The focus is put on exploring the specificities of the material culture complex among three distinctive Orochon groups, including the traditional occupations (hunting, reindeer husbandry, fishing), clothing, decorations, and beliefs, especially shamanism. I argue that the ethnic and cultural specificities of the Orochon material world should be seen as shaped by the people's adaptation to the local natural environment, influenced by the type of their economic and cultural activities as well as their belief system, and further altered in the course of their interaction with neighbor cultural groups.
\end{abstract}

This article is a translation of: Сем Т.Ю. Вещный мир оленных орочонов Забайкалья начала XX в. в пространстве культуры // Etnograficheskoe Obozrenie. 2021. No 4. Р. 191208. DOI: $10.31857 / \mathrm{S} 086954150016709-9$

A problem of the materiality in the society and culture holds a high position in the modern social and cultural anthropology. The science of things (realogy) is a traditional research topic in the Russian ethnography. It was discussed in Ethnographic Review journal in 2016. At present this agenda is determined by an ontological turn towards the materiality of the world of things in the sociology and is related to the concept by B. Latour, J. Law, K. Knorr-Cetina (Baranov 2016: 25; Sokolovsky 2016) which implies abandonment of the anthropocentrism, elimination of the subject-objectivity, parity of the metaphysical status of all objects, considering the things as "an active phenomenon of culture", hermeneutical approach to it (Sokolovsky 2016: 105). In the context of this perception A. B. Golovnev studies a thing as a live spirited phenomenon in the world's space which pervades "a live dialogue of a human being with the world" (Golovnev 1995: 197). D. A. Baranov notes the role of museums in studying the materiality and substantiates the modern approaches to it: studying a thing as a national specific artefact related to ethnic graphicness, ethnicity, ethnic attribution, analyzing things in the system of culture, reading constructive-and-technological and symbolic interpretations (Baranov 2016).

Tatyana Y. Sem | https://orcid.org/0000-0003-3306-3481 | semturem@mail.ru|Russian Museum of Ethnography (4/1 Inzhenernaia Str., St. Petersburg, 191186, Russia)

Etnograficheskoe Obozrenie. 2021. № 4. P. 343-356. https://doi.org/10.31857/S086954150016804-4

(C) Russian Academy of Science | (C) Institute of Ethnology and Anthropology, RAS

ISSN 0869-5415 | http://journal.iea.ras.ru 
Understanding a hand-made thing as an «own» product, differing from an «alien» one, is one of the elements of ethno-cultural specifics displayed in symbols and objects of value. The material objects constitute the basis for human activity and ethnic culture and are related to spiritual interpretation of the world. Household and welfare items, clothes and sacred items which have different semiotic status (Baiburin 1995: 82) characterize the traditional ethnographic complex of the community and form its ethnic identity in interaction with the other groups.

The purpose of this work is to describe ethnic peculiarities of the traditional culture of Transbaikal Orochons dated to the early 20th century based on the things from the collection of the Russian Museum of Ethnography (hereinafter - REM). The objectives of this work are to specify general and local specific features of the traditional culture of Transbaikal Orochons, to show its place in the cultural system of the Evenkis, to identify the ethnocultural ties between different groups of the Evenkis using the above mentioned materials.

The author of this work believes that the most imminent of all features of the modern theory of materiality are the hermeneutical approach of reading a thing as a text of culture, its studying in the cultural system, revealing meaning and purpose of things, defining their functions and semiotic status.

The work scientific novelty is in the fact that REM collections were first systematically studied for the reindeer groups of Transbaikal Orochons dated to the early 20th century.

The closely associated notions "ethno-cultural specifics of the world of things" and "the traditional ethnographic complex" are used in this work with respect of the above-mentioned community. The ethno-cultural specifics of the world of things for an ethnic group is determined through analysis of specific elements of its culture which are manifested by the most characteristic and widespread things of living activity/life support, social-regulatory and cognitive activity. And the ethnographic complex suggests a characterization of these ethnic specific elements in the cultural system.

The issues of studying things of the Evenkis and Orochons were earlier considered in several works based on study of collections of the Museum of Anthropology and Ethnography, Russian Academy of Sciences (RAS) (hereinafter - MAE RAS) (levin, Potapov 1956; 1961; Vasilevich 1969; 1976; Prokofieva 1971). A number of the recent works pay great attention to analysis of things related to way of life and faiths of these peoples (Mazin 1992; 1984; Dyachenko, Ermolova 1994; Sirina 2012; Brandisauskas 2019). The culture of Transbaikal horse Orochons (the Murchens, Hamnegans) was studied by several scientists (Shubin 1973; Tugolukov 1975; Uvarova 2005; Povoroznyuk 2011). The academic researchers contributed significantly to analysis of the world of things of the Evenkis and Orochons, however the material on Transbaikal reindeer Orochons was hardly used. This makes the study of things of this group of Transbaikal Orochons pertinent.

REM holds seven unique collections for Transbaikal reindeer-breeding Orochons of three local groups -Nerchinsk, Severobaikalsk and Tungiro-Olyokminsk. These are five collections for the Orochons of Nerchi river from the collection of A. A. Makarenko (1913) (REM: Coll. 5093, 6761) and his correspondents G. N. Leontiev (1911) (REM: Coll. 2651) and D. M. Golovachev (1909-1910) (REM: Coll. 1922, 1923) as well as two collections of Tunguska expedition of 1927-1928 (REM: Coll. 8761, 8762) purchased by a prominent Moscow ethnographer, member of stuff of Museum of Peoples of the USSR M. G. Levin. These things were collected from three families of Severobaikalsk Evenkis - Kindigirsk (Dushkachany settlement), Chilchagirsk (Upper Angara, Ashinkan territory, Arbiklya river and Irkona village) and Shamagirsk (Tompa river mouth). For the third group of the Orochons - from Tungira river and Olyokma wintering - REM holds the collection of D.M. Golovachev (REM: Coll. 1922). The total number of the studied things is 526 of which 79 things are in the collection of 1922, 10 - in the collection 2651, 81 - in the collection of 1923, 242 - in the collection 5093, 96 - in the collection of M. G. Levin (8761, 
8762). These materials have not yet been introduced for scientific use that is why their analysis is of particular value.

According to the Russian ethnographic science, the Orochons belong to a territorial group of the Evenkis of Transbaikal, Upper Amur river and Greater and Little Khingan Mountings of Manchuria. S. M. Shirokogorov, who visited Transbaikal in 1912-1913, thought that they spoke Nerchinsk and Bauntovsk sub-dialect (Shirokogorov, Shirikogovorova 1914: 144). According to G. M. Vasilevich, the Orochons language belongs to dialects of Verchnealdansko-Zeya-Amur groups (Vasilevich 1956: 702). The Chinese scientists distinguish the Orochons and Evenkis as the autonomous peoples along with the Solons (Tsu $\mathrm{Pu}$ Shu 1956: 1). According to the work by A. S. Shubin, Transbaikal Evenkis are divisible into several groups: Barguzin, Armaksky, Nerchinsk horse, Northbaikal, Bauntovsk and Vitimo-Tungiro-Olyokminsk (Shubin 1973). T. B. Uvarova specifically studied Nerchinsk group of the horse Evenkis (Uvarova 2005). As mentioned above, REM collection holds collections for the reindeer-breeding groups of Nerchinsk, Northbaikal and Tungiro-Olyokminsk Orochons.

There are several points of view with respect to ethniconthe Orochons. According to the earliest one, of oriental studies, it traces its origin to Manchurian name of the Evenkis oroncho (or urun-chun) - reindeer-breeding (Zakharov 1875: 132; Patkanov 1906: 2). The Manegrs (Kumarchens) and Birars were thought belonging to the Orochens of Manchuria (Tsu Pu Shu 1956: 1). When describing peoples of Amur region R. K. Maak makes a distinction between the Orochons as such, Manegrs and Birars (Maak 1859). The name Manegrs derives from the name of a territorial group of the Evenkis of Manyagir family (Vasilevich 1969: 10). G. M. Vsilevich thought that ethnicon the Orochons, known from the 17th century, traces its origin to the name of Oro district on the upper reaches of Amur river (Vasilevich 1963: 71-73; 1969: 11-12). N. V. Ermolova and V. I. Diachenko noted that "the name Orochons, originated as Manchurian name for the reindeer-breeding population, originally did not have any ethnic meaning $\langle\ldots\rangle$. But eventually...the term assumed also an ethnic meaning" (Diachenko, Ermolova 1994: 18). This ethnicon is in wide use among the Evenkis and Evens (Sirina 2012: 43-48), and it is also used in the Russian-language lexicon to denote the Ulta of Sakhalin (Missonova 2006: 55-61).

Being the reindeer herders in the 17th century, a part of the Orochons - the Manegrs and the Nerchinsk steppe nomads - switched over to horse breeding under influence of the Daurs, Buryats and Mongols. The steppe Nerchinsk Orochons were living in Barguzinsky and Kurumkansky districts of Buryatia and named themselves The Murchens (the horse Evenkis). The neighbouring Buryats gave them the name the Khamnigan (Sirina 2012: 48).

In May 1858, according to Russian-Chinese Treaty of Aigun, the territories along the left bank of Amur river from Argun river to its mouth were ceded to Russia, the Amur region was divided into two: Amur and Primorsk regions. In another ten years, owing to the resettlement policy, 18642 Russians lived on Amur territory (Kabuzan 1973: 47, 63-66, 78), and Russian influence on the indigenous groups became noticeable in the contact zone.

According to the census of 1897, 1629 Orochons, of these 677 Amur and 952 Transbaikal Orochons, were counted in Baikal and Upper Amur lands (Patkanov 1906: 12, 14). Three groups of the Evenks-Orochons (Nerchinsk, Vitimo-Olyokminsk and North-Baikal Orochons: in total, according to M. G. Levin, 800 people), which collections are held in REM, were descendants of the late migrants from the northern areas of the upper reaches of Amur and Lena rivers neighbouring with some local families - Kindigir, Chilchagir and Shamagir. A small part of the Manegrs (160 people) (ibid: 157), judging by the collections purchased for REM in 1910 by D. K. Soloviev, continue to inhabit territories of Zeya river (Sem 1986) while their main body moved to China to Kumaru river where they became known under the name the Kumarchens. The Birars also moved to Manchuria - this is clear from the fact that they were considered the Chinese subjects (Maak 1859: 312-315; Patkanov 1906: 155-164; Sirina 2012: 51; Shirokogorov 2017: 217-224). 
Materials from REM collections for the mentioned three groups of the Orochons show that the taiga reindeer-breeding groups also lived on the Transbaikal territory along with the steppe Nerchinsk horse breeders in the end of the 19th - the beginning of the 20th century. This is also confirmed by the expedition data by S. M. Shirokogorov who was to these groups in 1912-1913 (Shirikogorov, Shirokogorova 1914: 133-134) and took a census of the local Orochon families (Shirokogorov 2017: 215-217).

The things from REM collections related to the main activities, domestic life and beliefs of Transbaikal reindeer-breeding Orochons are classified in this work.

Hunting, reindeer-breeding, fishery artefacts. The Orochons cultural specifics are firstly based on peculiarities of their natural habitat in the mountain taiga forest and type of economic and cultural activities of the taiga hunters-reindeer breeders as well as on the traditional world outlook and rituals (Shirokogorov 1935; Ermolova 1999: 45-60; Sirina 2012). A. Lavrillier and S. Gabyshev noted, when describing the Arctic knowledge systems of the indigenous groups: "The nomads have great opportunities for development and translation of their knowledge". And, according to the Evenk shaman's daughter, they are "professors in knowledge of the habitat and in ability to exist in it" (Lavrillier, Gabyshev 2017: 17).

In the end of the 19th - beginning of the 20th century, according to Charter of the Aborigines Governance of 1822, the Evenks-Orochons were assigned to wandering groups of the Siberian population (Levin, Potapov 1956: 706). They led a life of the taiga huntersreindeer breeders which corresponded to the common Tungus tradition but for all that they kept horses and reindeers for transportation, fishery was also important for them, in terms of trading as well, while foraging was developed mainly for the family needs.

Hunting. Hunting for large meet animals - Manchurian elk, deer, roebuck, musk deer as well as hunting for bear, fur animals and birds played the main role in the diversified farming for all groups of the Evenkis. Special tools allowed them to get animals in the taiga using active (with the help of rifle, lance, palma, bow) and passive (with the help of catchers, traps) methods.

Judging by REM collections, in the beginning of the 20th century Transbaikal Orochons hunted with the use of simple bows (REM: Coll. 1922-70, 8761-8558) with arrows, crossbows (REM: Coll. 1922-72 a-d; 6761-1-4), palmas - single edge blade hunting knifes attached to a long handle (REM: Coll. 1922-25aб; 5093-2ab) and other hunting knifes (REM: Coll. 5093-4ab, 54ab) typical for all groups of the Evenks. Also used were catchers, snares and traps - dead falls (REM: Coll. 8761-8559, 1992-71ab) which were borrowed from Russians. In the end of 19th - beginning of the 20th century the Orochons actively used fire-arms of the flint-gun type (REM: Coll. 1922-69/4) which were purchased from Chinese merchants. Besides, they purchased rifles with lead bullets from Russian merchants at many Transbaikal trade fares (REM: Coll. 5093-230ab, 231/2) (Sem 2015).

The Orochons of Tungir and Olyokma and North Baikal region still used bows in the 1st-2nd decades of this century. For example, berkan (ber, berkan - common Tungus naming units) of the Orochons of Shamagir family from Tompa river, brought by M. G. Levin form 1927-1928 Tunguska expedition, represented a simple design made of an arched stick, $1 \mathrm{~m} 10 \mathrm{~cm}$ long, and a string; a cover for its fastening was not present (REM: Coll. 87618558). Tungir-Olyokma Orochons had a similar bow (REM: Coll. 1922-70). A similar weapon was known to Amur Orochons and peoples of Lower Amur (the Nanaians, Ulchis, Orochis, Udege, Nivkhs) and, probably, was common for the Tungus-Manchurians (Mazin 1992: 82; Levin, Potapov 1956: 793; Smolyak 1984: 88-89). Amur Orochons glued the bow over with birch bark, and a tendinous cord was laid on the inside (Diachenko, Ermolova 1994: 43). Those bows, unlike Transbaikal ones, had special shaped recesses to fasten the string (Mazin 1992: 82).

Based on the materials dated to 17th-18th centuries and illustrations by I. Ides it is possible to make a conclusion that the Evenk hunters from Angara river had a big compound bow with the length of about 2 m (Ides, Brand 1964: 124; Georgy 2005: ill.). The same type 
weapon with covering made of bone or birch bark was known to the Evenkis from the Yenisei river and the Evenkis from the sea of Okhotsk in the end of 19th - beginning of the 20th century, the latter also used whale fin for the bow covering (REM: Coll. 974-4, 2601-1, 1217-15). G. M. Vasilevich noted that in the 19th century Transbaikal Evenkis used a big compound bow ber (or nong) (Vasilevich 1969: 62-63). Mongolian peoples also used a compound double-concave big bow with birch bark covering which was similar to that used by Angarsk, Yenisei and Transbaikal Evenkis (Ermolov 1987: 151-152). It is known that the Evenkis sold such weapons to Amur people. The compound bow was notable for increased hitting range and was very comfortable for hunting at barrens in open terrain where the Eastern Evenkis lived. It is not available in the collections - this thing is difficult to buy because of its great value.

In the beginning of the 20th century Nerchinsk and Tungiro-Olyokminsk Orochons used crossbows, along with bows, and named them berken, North Baikal and Bauntovsk Orochons used another name for them - alanga (Vasilevich 1969: 64). Crossbows for hunting deer, Manchurian deer, wild goat, musk deer and fur animals (sable, fox, otter) (REM: Coll. 1922-72, 6761-1-4) which were brought from Nerchisk Orochons are held in REM collections. Length of these bows varies from 77 to $127 \mathrm{~cm}$. Crossbows were used by different Siberian peoples including Amur region. They were comfortable fur killing animals at a short distance without presence of the hunter, especially at barrens.

The palma utkon - a single edge blade massive knife (29-45 cm long) attached to a long handle covered with birch bark (60-74 cm long) (REM: Coll. 1922- 25, 5093-2ab) played an important role amongst the hunting tools of Transbaikal Orochons from Nerchi, Tungir and Olyokma rivers. Besides, the Orochons used the lance gida with a double-edge blade (1575 cm long) (REM: Coll. 5093-3) for hunting wild deer and bear. The palma and lance were the common hunting tools of all groups of the Evenkis.

When wild deers on heat, Transbaikal and North Baikal Orochons widely used different callers orevun (or amaka) (Nerch.): pipes twisted of birch bark or wooden pipes consisting of two halves (37-49 cm long) they used for hunting Manchurian elk, moose, deer (REM: Coll. 5093-6, 7; 8761-8560), whistles pichaun made of twisted birch bark were used for hunting musk deer (REM: Coll. 5093-229). Similar callers were used by Zeya and Manchurian Manegrs. Use of such pipes was a feature of hunting cloven-hoofed animals by Eastern Evenkis (Sem 1986: 96).

Personal equipment of the Orochons from Tungir and Olyokma, North of Transbaikal and Great Khingan Mountains normally included ponyaga - a fixture for carrying loads on the back (REM: Coll. 8761 - 8566; 1922 -63abc). A cross serving as a guard against demon spirits and as a decoration is depicted on one of the ponyagas belonging to a hunter from Kindigirov family of Dushkachany settlement (REM: Coll. 8761-8566). Several belt-worn hunting knives are stored in REM collections. Normally they were made of iron, had a wide triangle blade sharpened on one side, a wooden handle $(30 \mathrm{~cm}$ long) and leather or birch bark sheath (REM: Coll. 8761-8561, 1922-9, 5093-4ab, 5 ab, 49, 1ab). A hunter going to taiga in winter would put on non-slipping skis kinna (or uledgi) (148 cm long, $23 \mathrm{~cm}$ wide) (REM: Coll. 1922-26) and hunting goggles of wood with narrow slits to protect from snow shine (REM: Coll. 8761-8562).

A part of the hunting objects names came, in ancient times, to the Evenki language from the Mongolian language (nemki - bow, shoot from a bow; tol, tele - belt for tying tops of fur boots; hurka - loop, snare for birdcatching, etc.). Borrowing from other languages is also observed (Chimitdorzhieva 2012: 51-56, 80, 98).

Thus ancient all-Tungus elements and East-Tungus features (crossbows, pipes orevun) are observed in hunting practices and tools of the Orochons. Some Lower-Amur (simple bow) and common with East Asia (compound bow) components were also present.

Fur skins were used to pay tribute and for trade exchange. "Twice a year, by the end of January and by mid-July, the Tungus would go to trade fairs" (Sirina 2012: 218). Many trade 
fairs took place in Transbaikal and Southern Yakutia (Missonova 2018: 109-127). The Evenkis were trading with Russian and Yakut merchants, while the Manegrs and Orochons - not only with those but also with the Chinese. The Orochons, as all other Evenkis, were selling fur skins and skins of the clove-hoofed (squirrel, roebuck, fox, deer, musk deer, sable, otter), dried meat of bear and Manchurian elk, cabardine musk which was highly valued in Chinese medicine, cloths. In turn, they were buying gunpowder, rifles, flour, bread, lard, butter, tobacco, matches, salt, sugar, tea, vodka, cereals, fabrics, iron, steel kitchenware, metal bijouterie, bronze Chinese mirrors (Sem 2015). There existed the state policy of supplying the Tungus with goods against rent of rivers. A. A. Sirina and V. N. Davydov provide specific data on trade of the Shemagirs (Sirina, Davydov 2017).

Reindeer breeding. Talking about the Evenkis life, A. A. Sirina notes that "reindeer breeding, along with hunting, is important for the peoples national identity and their social mobility, for the best personality manifestation" (Sirina 2012: 239).

Pack-riding (transportation) reindeer breeding was a characteristic feature of Transbaikal Orochons (Vasilevich 1969: 72-86; Mazin 1992: 70). Moreover, they hunted on reindeer back (Tugolukov 1969: 2). G. M. Vasilevich reported about two types of reindeer breeding practiced by the Evenkis - the Evenki type and Orochons type. The western, Evenki, type assumed availability of a small herd, using reindeer for load-packing, nomadizing on foot - no riding saddle. The eastern, Orochons, type assumed a big herd, keeping reindeer both for load transportation and hunting on reindeer back, nomadizing with reindeer herd (Vasilevich 1969: 7577). Among Transbaikal Orochons, North Baikal Evenkis practiced the first type while Tungir and Nerchin Evenkis - the second type.

The objects related to caring for reindeer indicate that the reindeer breeding was a priority area of the Orochons life. According to the author's field materials which registered frequency of use of reindeer images and in the eyes of the Evenkis from Iengra and Kharialakh settlements the reindeer image is a symbol of their culture. It was reflected in mythology, religious faiths, including shamanism, in traditional and contemporary art (rugs, panels). Animal care was mainly occupation for men which was a specific feature of the Orochons type of reindeer breeding (Vasilevich 1964: 5). "Natural rugged terrain was used for grazing" (Sirina 2012: 224; Davydov 2014). As reported by M. G. Levin, reindeer herds of North Baikal Orochons did not generally, wander far into taiga, and in winter time were walking with bells around their necks or with wooden clappers and hamshackles on legs to make it easier to fins them (Levin 1936: 73). A wooden clapper modon-mukon with a bone tongue ( $31.5 \mathrm{~cm}$ long) and a hamshackle for young reindeer leg puttsa $(31 \mathrm{~cm}$ long) was brought to the museum by a collector from the Kindigirs (REM: Coll. 8761-8564).

Dehorning was done in August, prior to reindeer mating season, with the use of a special saw in the form of a frame with a steel saw-edged pate. Such a saw of the Northern Transbaikal Kindigirs is decorated by a reindeer image (REM: Coll. 8761- 8565). The main ancient method of reindeer castration used by the Evenkis was testicular biting while it is known that the Transbaikal Orochons used a method of scrotum cutting using knife according to stock-breeding principle of Central Asia peoples (Vasilevich 1969: 72; Sirina 2012: 228). From Nerchin Orochons A. A. Makarenko brought a knife kotokam (blade width of $3.7 \mathrm{~cm}$ ) with a bone handle (length of $6.5 \mathrm{~cm}$ ) in a stone sheath (REM: Coll. 5093-12ab) which was used for that purpose. There is no such knife in the collection received from the Western Evenkis. S. M. Shirokogorov noted that castration with the use of a knife was introduced later than castration through the testicular biting, however the first method is regarded as the best (Shirokogorov 2017: 73). When caring reindeer, the Evenkis would make a smoky fire and shaded shelters, erect hedges and paddocks (Diachenko, Ermolova 1994: 50; Sirina 2012: 221-231).

Snaffle-bits ushi (orukhsh) (Nerchin) of Sayan type in the shape of a long hide rope with a big loop were used for taming animals. It was put on the animal muzzle above the eyes; two laces inmar were knotted at the neck behind the horns (Vainshtein 1971: 41). Similar 
snaffle-bit was brought by M. G. Levin fron the North Baikal Orochons from 1927-1928 Tunguska expedition (REM: Coll. 8761-8563) and by A. A. Makarenko and D. M. Golovachev - from the Nerchin Orochons. Triple pigtails made of textile material and fur were suspended on the bridle near the reindeer cheeks, under the beard - trusses made of wool which served as protective amulets (REM: Coll. 5093-76; 1922-66).

During calving Transbaikal and Amur Orochons as well as the Yenisei Evenkis women were milking female reindeer and served milk for tea and with berries in milk pails achachan in the form of a round cup made of birch bark with a wooden rim (diameter of $1575 \mathrm{~cm}$ ) (REM: Coll. 5093-11). Special bags with salt were used for reindeer alluring; they were made of rovduga (deerskin chamois), had a trapezium form and were decorated with colored textile strips and pendants made of teethed jaws and hooves of a reindeer fawn (length of 14 $\mathrm{cm}$, width of $9 \mathrm{~cm}$ ) (REM: Coll. 5093-13).

The reindeer tools for fastening load packs, riding in saddle and on sledges demonstrate the active lifestyle of the Evenkis-Orochons in taiga associated with quick long-range movement. Different types of reindeer saddles were used for training the young Orochons, transporting loads and riding in saddle which were put on the animal back and fastened by a belly band.

Judging by REM collections, the riding saddles neme (or lacheko) (North Baikal), lochako (Nerchin), otygon (Nerchin) (5093-82, 83) used by the Orochons from Yablonovy and Stanovoi Ranges had a bone saddlebow attached to two wooden ledges bounded by fur sacks and a bone plate gilbaun for lashing the bridle of the next reindeer in the caravan (REM: Coll. 1922-22 (saddle length of $36 \mathrm{~cm}$, width of $26 \mathrm{~cm}$ ), 1922-68 (saddle length $42 \mathrm{~cm}$, width between the saddle bows of $35 \mathrm{~cm}$, height $19.5 \mathrm{~cm}$ ), $8761-8595$ (plate)). The saddle bow and plate used by The Baikal Orochons are decorated by a geometric pattern in the form of stripes, arches, zigzags, diamond shapes which differ from ornament with combination of curvilineal and geometric pattern used by the Amur and Manchurian Orochons.

The Orochons pack saddles did not have the fur sacks and were of two types.Danne represented two wooden ledges connected to each other by straps in the center; amegen had a high and wide saddle bow made of wood or bone which were blackened and decorated by geometric and curvilineal pattern (REM: Coll. 1922-22; 8761-8595; 5093-73, 74, 81; $8761-8593,8594)$. It is interesting to note that this type of the saddle bow decoration - with blackening and stripe or curvilineal pattern - was also observed on the objects used by the Sakhalin Evenkis and Uilta (PMA 1986; PMA 1988) (PMA - author's field materials).

According to the opinion of G. M. Vasilevich, the Orochons pack saddle emegen originated from the Mongolian riding saddle emeel and was adopted from horse breeders (Vasilevich 1969: 78; 1976: 107). Based on horse breeding terminology used in reindeer breeding of the Tungus, G. M. Vasilevich and M. G, Levin make a conclusion about development of the Tungus reindeer breeding under influence of the Mongolian horse breeding (Vasilevich, Levin 1951: 85). A. I. Mazin also believes that the Orochons knew about the reindeer riding even before meeting the horse breeders, they used the bridle and belly band, pack-riding saddle danne which later was transformed into the pack saddle (Mazin 1992: 117-118). According to study by S. I. Vainshtein, saddle-trees of the Tungus saddles were identical to saddle-trees of the most ancient Sayan pack saddles. The fact that the Tungus sewed the saddles round is related to the horse breeding tradition dated to the Pazyryk times. However, origin of the Tungus saddles can not be explained by influence of the Mongolian horse breeders due to differences in the design. He explains transfer of the Mongolian horse saddle name to the pack saddle of the Tungus reindeer breeders by the fact that the Transbaikal Tungus used the horse saddle (Vainshtein 1971: 28-29, 44).

The balancing stick for the reindeer riding played an important role in the Evenkis reindeer breeding. The stick was not just for practical use but also had a sacred meaning. A. A. Sirina believes that it was used when moving in the taiga and as the grave goods - for the difficult 
travels of the soul (Sitina 2012: 231). According to our field materials, a decoration in the form of three concentric circles, symbolizing three suns of three worlds of the universe, could sometimes be observed on the upper part of the stick which was made of iron and even silver. Thus, the stick's tip incarnated Space and, probably, was associated with the tree of the three worlds (PMA 1988; PMA 1994).

Two saddle bags, secured to each other, inmok (common for the Evenkis) or gucha rukk potka, tureuchka (Nerchin) were loaded on the pack saddle. These bags were used for flour transportation. They were designed as a birch-bark bin of the diamond shape and were pulled over with covers made of deerskin chamois or reindeer gaskin skin and decorated by colored textile strips and deerskin chamois tassels with beads (REM: Coll. 8762-19231, 19234; 5093-84ab). M. G. Levin noted that the North Baikal Evenkis attached woman's bags muruchun, round- or eight-shaped, between the saddle bags (REM: Coll. 8762-19235, 19236). Children were carried in cribs of the Tungus type mama bo (REM: Coll. 8761$8596 ; 1922-28,29)$; it was tied up on the one side and counterweighted by hanging a saddle bag on the other side (Levin 1936: 73).

Fishing. Fishing was a seasonal activity in the Transbaikal and North Baikal EvenkisOrochons household in the end of the 19th - beginning of the 20th century, and played an important role, along with hunting and reindeer breeding, which was an ethno-cultural feature of this group of the Evenkis. Fishing was of great significance for the Shamagirs of North Baikal and Amur region (Sirina 2012: 239).

There are only two objects related to fishing activity of the Transbaikal Orochons in REM collections. Those are netting devices purchased from the Nerchin Orochons; such device is comprised of an oblong shaped wood board (length of $66 \mathrm{~cm}$, width of $9 \mathrm{~cm}$ ) (REM: Coll. 6761-18) and fishing line winded on hooks (REM: Coll. 5093-133/2). Judging by M. G. Levin's collections, the North Baikal Orochons of Chilchagarsky family from Chencha settlement were using a fish-bait which was made of wood and covered by lead plates, a piece of red textile was attached to it (REM: Coll. 8761-8567ab). It is interesting that the Baikal Neolithic population also used fish-bait made of bone (Okladnikov 1950). However the fishing gear, common to all the Evenkis and Orochons as well as Amur peoples - a trident kiramki, a spear elgu, a harpoon debge (Vasilevich 1969: 80-82; Sirina 2012: 239) were not brought by the collectors which probably reflects their importance in the household.

Clothes. Clothes play protective, aesthetic, symbolic roles in the culture of the peoples (Kalashnikova 2000: 4-5). Clothes reflect the ethnic view of the world and perception of the human body. The main specific features of the Tungus caftan and footwear were studied by G. M. Vasilevich in special papers based on the clothes items collected from the western and eastern groups; however there are few papers on the Transbaikal reindeer breeding Orochons clothes (Vasilevich 1958: 122-178; 1963: 3-64). Analysis of REM collections fills this gap.

In the beginning of the 20th century, along with the traditional type of clothes, the Transbaikal Orochons had clothes made under Russian influence, for instance shirts of flannel with a straight short cut on the breast (REM: Coll. 5093-107). The cut of the traditional costume worn by the Nerchin Orochons belongs to a mixed Tungus-Turkic type. It was double-leaved, with a breast piece, as with The Tungus, or without it, but it had strait back and ruffles on the sides, as with The Sayan-Altai Turkic.

By the end of the 19th - beginning of 20th century the style of the Evenk traditional women's clothes was better preserved than the men's clothes style. Women's outer summer caftan (doshka) torgandy of the Nerchin Orochons was made of buckskin, sometimes orange-colored using alder, or made of cotton fabric purchased from Russian merchants which imitated buckskin. It was double-leaved, knee-long, with straight flaring back and foreparts, ruffles on the sides, sleeves were loose narrowing to the wrist, and the collar was of turn-down style. Skirting, flaps and collar of one caftan from REM collection were 
bounded with frilling of red bunting and blue dabu, another caftan was bounded by black strip (REM: Coll. 5093-90, 1922-1). The cut differed from the Tungus cut with two panels at the bottom, probably the ruffles replaced them. The straight back reflects the Turkic influence. Women of Chilchagirsky family of the North Baikal Orochons wore the summer caftan of the style which was much as the style of the Nerchin group women caftan (REM: Photocoll. 18303/2).

In winter the latter wore clothes doshka of reindeer skin, fur inside, of a similar cut. Doshka from REM collection has metal buttons - ten on each forepart; breasts are bounded with frilling of blue dabu with red rim (REM: Coll. 5093-89) - this is a common decoration of caftans worn by the Yenisei Podkamennaya (Stony) Tunguska Evenkis. It is interesting to note that clothes of similar style, with the side ruffles instead of panels, have some similarity with clothes of the Dolgans and represent a Turkic element characteristic for the Sakhalin Oroks. In winter the North Baikal Orochons, men and women, wore slim fit fur coats kupo Only old women wore the front pieces (Archives REM 1: Archive fund 5. Op. (List of files) 4. File number. Coll. 27. KP 36474).

Collection of A. A. Makarenko holds a set of clothes for a young woman brought from the Nerchin Orochons. It preserved the archaic Tungus type of the split clothes. It includes the upper double-leaved caftan doshku with a tight-fit back and two pleats on the sides, a breast piece-apron with a breast inset in the form of loom bird leg, a textile shirt of Russian cut, buckskin trousers, knee pieces aramus, buckskin boot-shaped footwear and a headband (REM: Coll. 5093-88an). Nowadays, the breast piece in the festive-ceremonial clothes of the urbanized Evenkis is reduced to a collar-decoration which is considered to be a sign of attribute to the Evenk society.

Men's clotheskupo of the Transbaikal Orochons made of roebuck or wild goat fur was of a typical Turkic cut and differed from women clothes. Thus, on Karenga and Nerchi rivers it was tailored as a double-leaved caftan with the length just below kneecap with a slight wrapover from right to left, slightly flared fronts and straight back (REM: Coll. 19227, 5093-91). In the end of 19th - beginning of the 20th century, In summer the Transbaikal Orochon men wore skewed-collared shirts and trousers of textile purchased from Russian merchants (REM: Coll. 5093-106). At this, the costume did not have the breast piece.

Along with caftan, the set of men's and women's clothes of the Transbaikal Orochons included worn-on-hips short trousers orki sewed of blue dabu, buckskin leather - deer or goat (summer), reindeer (winter). Based on the collections it is possible to state that the Orochon men's and women's trousers were decorated by a strip of blue dabu and buckskin fringe (REM: Coll. 8762-34207). Knee pieces aramus were put on the leg, from ankle to crotch, and tied up to trousers. Summer men's and women's knee pieces were sewed of crafted leather. The Orochons had special feelings for the clan guardians which, as was believed, were helping in life and crafts. Collection of A. A. Makarenko holds three amulets omokko representing such spirits as small ragged cross-typed dolls (REM: Coll. 5093-141/4, 5093-143). They are made by order by shaman to protect the family. One amulet is connected with a model of birch-bark crib (REM: Coll. 5093-142), the other one, made to attract luck in crafts, has a design of Y-shaped boar spear with six small human-like figures made of red copper - symbols of inhabitants of heaven - and horse and bird figures (REM: Coll. 5993-143 abcd).

Use of a stripe-type ornament, common to the Orochons for decoration of clothes and homeware (women's round bags, saddle bags), was characteristic for all groups of the Evenkis.

Footwear, being a part of the Orochons costume, is a most conservative element of culture reflecting the most archaic layer and preserved with the nomadic Evenkis up to the present day. G. M. Vasilevich was the first to study types of footwear of Siberia peoples (Vasilevich 1963). The fact that the Orochons and Evenkis had two types of footwear cut high boot type (REM: Coll. 8762-19187ab, 1922-5ab, 8, 35; 5093-99ab, 100ab) and 
piston type (REM: Coll. 5093-103ab) - indicates the existence of different cultural traditions - Amur (piston) (Vasilevich 1963: 43-45) and The Turkic (Xiongnu) (boots) (Viktorova 1980: 42, 46). The Amur Orochons decorated the bootleg top of red bunting with a range of curvilineal spiral or spiral-floral ornament and with eight-shaped figures and paired spirals with floral pattern on the sides or geometric pattern of alternate strips or diamond formations of white and dark fur (Mazin 1992: 139-140).

In summer the Orochons did not cover their heads and in winter wore round hats aun with cone-shaped crown and earmuffs of the Mongolian type made of goat leg fur or roebuck fur (REM: Coll. 1922-6, 5093-93).

Analysis of the Orochons clothes provides the very important information pertaining cultural identity of the studied ethnic group and Russian, Turkic, Lower Amur and Mongolian influence on it.

The objects related to traditional beliefs. Craft and family-ancestral cults as well as shamanism, associated with ancestor veneration, were widespread amongst the Orochons in the end of the 19th - beginning of the 20th century. Despite the fact that in the end of the 19th century the Evenkis were nominally christianized, they actually remained shamanists.

The Orochons activity in taiga was correlated with a system of craft beliefs, first of all with interactions with nature and local landscape spirits. Based on studies of cult strategies of the Evenkis-Orochons, D. Brandisauskas notes that and right now shamanistic art of controlling spirits, getting luck and safety is important for the Evenkis-Orochons. Different old and new ritual locations are important sources of knowledge, helth and strength (Brandisauskas 2019: 2, 17). Several studies discuss symbolics of the shamanic place of prayer and sacrifice (Yampolskaya 1993: 107-118; Klitsenko 2013a; 2013b). A.A. Sirina also publishes photographs of several sacred places - the shamanic place of prayer and sacrifice of the Katanga and Irkutsk Evenkis (Sirina 2012: 439, 443, 447, 450-452). Authors of the multiauthored monograph Fire, Water, Wind and Stone in the Evenk Landscapes discuss special relation between man and nature in the past and at present of the Transbaikal Evenkis (Davydov et al. 2016). REM collections complement significantly this information.

According to collection of M. G. Levin, in the forest the North Baikal Orochons-hunters carved out, on body of tree, likeness of spirit of the sky Bug or spirit of the region whom sacrifices were offered and which were asked for luck in activities (REM: Photocoll. 18293/1). The collection brought by A. A. Makarenko from the Nerchi Orochons holds offerings from the hunting place - branches with strips, duck head and skull of a small bird (REM: Coll. 5093-193). Two other hunting amulets belong to this collection: the one tiger figure mudyga (REM: Coll. 5093-138abcd), the second - figure of eagle Garo. The second figure is covered with deer skin and has a human face with a tin mask on it. In the Evenk minds, Garo is a spirit of hunting which carries the shaman soul to the Supreme Deity Buga (REM: Coll. 5093-69).

The Orochons had special attitude to the family-ancestral guardians which, as was believed, helped in life and activities. Collection of A. A. Makarenko holds three amulets omokko representing such spirits as small ragged cross-typed dolls (REM: Coll. 5093-141/4, 5093-143). They are made by order by shaman to protect the family. One amulet is connected with a model of birch-bark crib (REM: Coll. 5093-142), the other one, made to attract luck in crafts, has a design of Y-shaped boar spear with six small human-like figures made of red copper - symbols of inhabitants of heaven - and horse and bird figures (REM: Coll. 5993-143 abcd).

Special features of beliefs and shamanism of the Transbaikal and Manchurian Evenkis were specially studied by S. M. Shirokogorov who wrote a fundamental work on that subject Psycho-Mental Complex of the Tungus and by A. I. Mazin (Shirokogoroff 1935; Mazin 1984).

REM collections hold unique materials on shamanic places of prayer and sacrifice, shamanic clothes and amulets of the Orochons. The photograph collection of M. G. Levina, 
devoted to the North Baikal Evenkis, holds images of a shaman chum with four birch trees on the sides decorated with ribbons. This composition was installed by the Shemagirs for therapeutic purposes at the mouth of the Tompa River and represented a model of the world (REM: Photocoll. 18288/2). A. A. Makarenko brought back several objects from the shamanic place of prayer of the Nerchin Orochons (Gorbacheva and Solovieva 2006: 120, 200203). Among these items are special structures in the form of trees with nine crossbars and figures of ancestral spirits, anyakans, on top (RMG: Coll. 152-159). The crossbars symbolize the nine layers of the sky, where the shaman flew to during the therapeutic shamanistic ritual. Other objects are mokun offerings in the form of a pole with a deer skin and a goat, where the insides of the sacrificed deer were hung (REM: Coll. 5093-180-181) (Archives REM 2: Archive fund 6. Op. (List of files) 1. D. 215. L. 1). The collection also contains objects located on the passages from the shaman chum: figures in the form of a huge fish with deer horns (so the Orochons imagined the mammoth heli), images of deer, fish and anthropomorphic large images of anyakans from wood - family ancestors, which blocked the entrance of evil spirits from the upper and lower worlds to the world of people (REM: Coll. 5093-160, 161, 168, 171, 172; Archives REM 2: Archive fund 6. Op. (List of files) 1. D. 215. L. 8; Sem 2017).

Shamanic attributes of Transbaikal Orochons, judging from the collections of the REM, consisted of special clothes, masks, wands, amulets. These objects were collected from shamanic graves (ground and piled caches) or from sacrificial places by D.M. Golovachev from the Nerchin and by M.G. Levin from the North Baikal group.

Things from a grave from the Ashinkan area on the bank of the Arbiklya river, a tributary of the Upper Angara, belonged to a great shamaness Odokon of the Chilchagarsky family. They were reported by M.G. Levin's informer Pavel Fedorovich Tulbukonov, a blacksmith who made pendants to the costume (Archives REM 1: Archive fund 5. Op. (List of files) 4. D. 282, 302). Among her attributes are a mask, a tambourine with a stick and a wand. Particular attention is attracted by the shamanic shamashik costume (REM: Coll. 8762-19244), sewn from full-skinned elk suede, a double-leaved caftan with equal, convergent seams and breast pieces. The costume of such cut was connected with the group related to the Kets and Selkups (Prokofeva 1971: 45-48, 80). A detailed analysis was given in our special works (Sem 1987; 2017; 2018).

The second shamanic costume of the Orochons of Transbaikal from the collection of M.G. Levin is executed as a double-leaved caftan of Turkic type with a straight back. It is sewed from buckskin, orange-colored using alder, and for the best connection with spirits has numerous buckskin, fur and woven braids with beads on the ends. There are no iron pendants. Its decorations are characteristic of the shamanic clothing of the Amur Evenkis and symbolize a bird (Sem 2019).

Of the greatest interest is the ancient shamanic caftan described for the first time, brought by D.M. Golovachev from the Transbaikal Nerchin Orochons and taken from a cache above a shamanic burial place on the Nerchi River near the village of Kykeri. The preservation of the costume is poor, only the lower part of the caftan with a part of the foreparts and separate details registered under different numbers remain. The caftan of a shaman (REM: Coll. 1923-5a) is sewn from full-skinned elk suede, distinguished by its doubleleaved cut and has two triangular wedges at the back and a buckskin fringe at the front, which gives the costume the appearance of a bird. The skirting and edges of the foreparts are decorated with a black cloth strip. On the back there is an arkalan pendant in the form of a longitudinal strip of iron with deer horns and attached iron figures - animals (a deer, a bear, an elk), two pairs of men and a small bird (REM: Coll. 1923-12). Among the pendants there is also a buckskin transversal strip with six long buckskin snake figures bounded by blue cloth and deer hair (REM: Coll. 1923-10a). On the foreparts on the sides there are remnants of copper pendants in the form of ribs: thus the clothes symbolize the skeleton of a shamanic ancestor and reincarnation of a shaman into this spirit. In addition, iron pendants registered 
under different numbers belong to the costume (REM: Coll. 1923-13-23): figures of mammoth, animals, people and birds, as well as serpentine braids (REM: Coll. 1923-10). The presence of stitched metal white and bone pendants is curious. A buckskin strip with bone images of birds with outspread wings and bone concentric circles - symbols of the sun runs across the back and sleeves. Similar decorations complete the triangular wedges - the tail patch of the caftan. Eight figures of tigers made in China are stitched along the skirting on a black strip. This shamanic costume is dated to the beginning of the 19th century, based on the inscription on the bell "Slobodskoe, Vasily Makushin, 1817". Perhaps it was sewn earlier, at the end of the 18th century, as evidenced by the presence of bone pendants.

The shaman's costume includes two breast pieces (REM: Coll. 1923-5v-c), an iron crown with a crossbeam and iron deer antlers (REM: Coll. 1923-1), a buckskin headdress with three fringe circles and a back band decorated with bone patches in the shape of birds and circles (REM: Col: Coll. 1923-9(3)), high buckskin shoes with iron stylized deer figures (REM: Coll. 1923-26ab).

Also placed in the memorial air shed was a cut shaman's braid covered with colored cord (REM: Coll. 1923-11), three buckskin sacks with quartz, used for medicinal purposes, divination and fortune telling (REM: Coll. 1923-24a-c), shamanic birch canes with horny handgrips in the form of a horse head and images of hooves at the ends (REM: Coll. 1923$55 / 2$ ). Among the attributes of a buried shaman are two egg-shaped tambourines with three knuckles and sticks with bird heads carved on their handles (REM: Coll. 1923-53, 54). The amulets in the form of nine linked images of eagles (REM: Coll. 1023-67, 68) (Gorbacheva, Solovieva 2006: 121), wooden arches with the heads of a horse and figures of an elk (REM: Coll. 1923-61-67) attract special attention.

Several metal masks belonged to this shaman (REM: Coll. 1923-3/2, 81). One bundle of six masks stands out in particular: of white tin, brass, red copper and a wooden one with human teeth in the mouth (REM: Coll. 1923-2/6), for their photos with annotations see: (Gorbacheva, Solovieva 2006: 205).

On the basis of this study, the features of the object line of the three groups of the reindeer-breeding Transbaikal Orochons were revealed. The mapping shows that the greatest number of items in the collection is represented by the Nerchin group.

Attitudes to hunting and reindeer breeding tools and clothing among the Orochons of Transbaikal show that the ethno-cultural identity of this group belongs to the natural type. And the special status of sacred things and their residence in rituals reflect the mentality of representatives of shamanic culture. Many traditional objects of the Transbaikal taiga hunters-reindeer breeders continue to be used in modern everyday life, such as panyags backboards, bags for luring deer, deer saddles, saddle bags, shoes, breast ornaments with a protective amulet in the form of loom's leg (a sign of membership in the Evenk community), women's circular bags muruchun, circular and rectangular rugs with deer images. This testifies to the preservation of traditions and cultural memory.

Analysis of the material and sacral sections of the ethnographic complex of the Transbaikal Orochons and other Evenkis groups indicates that the culture of the former contains both common Tungus traits and its own specificity, reflected, for example, in reindeer-breeding (Samoyedic type of saddle, blood type of castration by Central Asian cattlemen), clothing (Tungus component, Turkic and Mongolian as well as Amur influence), ornamentation (Lower-Amur, North-Tungus type), Turkic and Tungus bases of shaman attributes. As a whole, in the traditional culture of Orochons, common Tungus and LowerAmur features are combined with elements of Turkic-Mongolian and Ket-Selkup influence.

For the first time the materials of the REM presented to a scientific turnover are an important historical and ethnographic source for the culture of the reindeer-breeding 
Orochons of Transbaikal which allows to consider a thing as a cultural text. With the publication of their analysis the possibilities of study, interpretation and comparison of elements and technologies of the already bygone culture of reindeer-breeding population of this region are extended.

\section{References}

Baiburin, A.K. 1995. Semioticheskii status veshchei i mifologiia [Semiotic Status of Things and Mythology]. In Kunstkamera: izbrannye stat'i [Kunstkamera: Selected Articles], edited by A.K. Baiburin, N.M. Girenko, and K.V. Chistov, 80-93. St. Petersburg: Evropeiskii Dom.

Baranov, D.A. 2016. O chem molchat veshchi [What Things Are Silent About]. Etnograficheskoe obozrenie 5: 25-39.

Brandišauskas, D. 2019. Leaving Footprints in the Taiga: Luck, Spirits and Ambivalence among the Siberian Orochen Reindeer Herders and Hunters. New York; Oxford: Berghahn Books.

Davydov, V.N. 2014. Issledovanie otnoshenii cheloveka i olenia v Yuzhnoi Yakutii [Research of Human and Deer Relations in Southern Yakutia]. In Materialy polevykh issledovanii MAE RAN. Vyp. 14 [Materials of Field Studies of the Museum of Anthropology and Ethnography of the Russian Academy of Sciences. Issue 14], edited by E.G. Fedorova, 95-117. St. Petersburg: MAE RAN.

Davydov, V.N., et al. 2016. Ogon', voda, veter i kamen'v evenkiiskikh landshaftakh. Otnosheniia cheloveka iprirody v Baikal'skoi Sibiri [Fire, Water, Wind and Stone in Evenk Landscapes. Relations between Man and Nature in Baikal Siberia]. St. Petersburg: Kunstkamera.

Diachenko, V.I., and N.V. Ermolova. 1994. Evenki iyakuty yuga Dal'nego Vostoka XVII-XXvv. [Evenks and Yakuts of the South of the Far East in the $17^{\text {th }}-20^{\text {th }}$ Centuries]. St. Petersburg: Nauka.

Ermolova, N.V. 1999. O prirodnoi i kul'turnoi obuslovlennosti etnicheskogo kharaktera evenkov [On the Natural and Cultural Conditionality of the Evenks' Ethnic Character]. In Etnos, landshaft, kul'tura. Materialy konferentsii [Ethnos, Landscape, Culture. Proceedings of the Conference], edited by L.R. Pavlinskaia, 45-60. St. Petersburg: Evropeiskii Dom.

Kabuzan, V.M. 1973. Kak zaselialsia Dal'nii Vostok (vtoraiapolovina XVII - nachalo XXv.) [How the Far East Was Settled (The Second Half of the $17^{\text {th }}-$ Beginning of the $20^{\text {th }}$ Century) $]$. Khabarovsk: Khabarovskoe knizhnoe izdatel'stvo.

Kalashnikova, N.M. 2000. Semiotika narodnogo kostiuma [Semiotics of Folk Costume]. St. Petersburg: SPGUTD.

Klitsenko, Yu. 2013a. Shamanskie chumy evenkov po materialam katangskoi ekspeditsii A.A. Makarenko [Shamanistic Chums of the Evenks Based on the Materials of the Katanga Expedition of A.A. Makarenko]. SibirskaiaZaimka: istoriia Sibirivnauchnykhpublikatsiiakh 14.03. . ru/klitsenkomakarenko/ (retrieved: 25.02.2020).

Klitsenko, Yu. 2013b. A.A. Makarenko o shamanskikh chumakh vitimo-olekminskikh evenkov [A.A. Makarenko about the Shamanic Chums of the Vitimo-Olekmin Evenks]. Sibirskaia Zaimka: istoriia Sibiri v nauchnykh publikatsiiakh 16.08. (retrieved: 25.02.2020).

Lavrillier, A., and S. Gabyshev. 2017. An Arctic Indigenous Knowledge System of Landscape, Climate and Human Interactions. Evenki Reindeer Herders and Hunters. Fflrstenberg; Havel: Verlag der Kulturstiftung Sibirien Publications.

Missonova, L.I. 2006. Uil'ta Sakhalina. Bol'shieproblemy malochislennogo naroda [Sakhalin Uylta. Big Problems of a Small-Numbered People]. Moscow: Nauka.

Missonova, L.I. 2018. Problemy i zakonomernosti lokalizatsii prostranstva provedeniia yarmarok na Severo-Vostoke i Vostoke Rossii [Problems and Regularities of Localization of the Fair Space in the North-East and East of Russia]. Rossiia iATR4: 109-127.

Povorozniuk, O.A. 2011. Zabaikal'skie evenki: sotsial'no-ekonomicheskie i kul'turnye transformatsii v $X X-X X I v v$. [Transbaikalia Evenks: Socio-Economic and Cultural Transformations in the $20^{\text {th }}-$ $21^{\text {st }}$ Centuries]. Moscow: RAN.

Sem, T.Yu. 2017. Shamanizm evenkov (po materialam Rossiiskogo etnograficheskogo muzeia) [Shamanism of the Evenks Based on the Materials of the Russian Ethnographic Museum]. St. Petersburg: Gumanitarnaia akademiia.

Shirokogorov, S.M. 2017. Sotsial'naia organizatsiia severnykh tungusov (s vvodnymiglavami o geografii rasseleniia i istorii etikh narodov) [Social Organization of the Northern Tungus (With Introductory Chapters on the Geography of Settlement and the History of These Peoples)], edited by A.A. Sirina and V.N. Davydov. Moscow: Nauka; Vostochnaia literature. 
Shubin, A.S. 1973. Kratkii ocherk etnicheskoi istorii evenkov Zabaikal'ia (XVII-XXvv.) [A Brief Sketch of the Ethnic History of the Evenks of Transbaikalia (1 $7^{\text {th }}-20^{\text {th }}$ Centuries) $]$. Ulan-Ude: Buriatskoe knizhnoe izdatel'stvo.

Sirina, A.A. 2012. Evenki i eveny v sovremennom mire. Samosoznanie, prirodopol'zovanie, mirovozzrenie [Evenks and Evens in the Modern World. Self-Awareness, Environmental Management, Worldview]. Moscow: Vostochnaia literatura,

Sirina, A.A., and V.N. Davydov. 2017. “...Ne imeiushchie ni khlebopashestva, ni skotovodstva, ni olenei, a tol'ko odnu lish' reku etu": paternalizm i rynochnaia ekonomika v Severo-Vostochnom Pribaikal'e [".Having No Arable Farming, No Cattle Breeding, No Deer, but Only This River": Paternalism and Market Economy in the North-Eastern Baikal Region]. Etnograficheskoe obozrenie 1: $70-85$.

Sokolovskii, S.V. 2016. Material'naia semiotika i etnografiia material'noi kul'tury [Material Semiotics and Ethnography of Material Culture]. Etnograficheskoe obozrenie 5: 103-115.

Tugolukov, V.A. 1969. Sledopyty verkhom na oleniakh [Pathfinders Riding on Deer]. Moscow: Nauka.

Tugolukov, V.A. 1975. Konnye tungusy (etnicheskaia istoriia i etnogenez) [Horse Tungus (Ethnic History and Ethnogenes)]. In Etnogenez $i$ etnicheskaia istoriia narodov Severa [Ethnogenes and Ethnic History of the Peoples of the North], edited by I. S. Gurvich, 78-110. Moscow: Nauka.

Uvarova, T.B. 2005. Nerchinskie evenkivXVIII-XXvv. [Nerchinsk Evenks in the XVIII-XX centuries]. Moscow: Institut informatsii po obshchestvennym naukam RAN,

Vainshtein, S.I. 1971. Problema proiskhozhdeniia olenevodstva v Evrazii. Ch. II: Rol' saianskogo ochaga $v$ rasprostranenii olenevodstva v Evrazii) [The Problem of the Origin of Reindeer Husbandry in Eurasia. P. II: The Role of the Sayan Hearth in the Spread of Reindeer Herding in Eurasia)]. Sovetskaia etnografiia 5: 37-52.

Vasilevich, G.M. 1969. Evenki. Istoriko-etnograficheskie ocherki (XVIII - nachalo XX v.) [Evenki. Historical and Ethnographic Essays (18 ${ }^{\text {th }}-$ Early $20^{\text {th }}$ Century)]. Leningrad: Nauka.

Vasilevich, G.M., and M.G. Levin. 1951. Tipy olenevodstva i ikh proiskhozhdenie [Types of Reindeer Husbandry and Their Origin]. Sovetskaia etnografiia 1: 63-87.

Yampolskaia, Yu.A. 1993. "Shamanskii chum" evenkov: istoriia otkrytiia, rezul'taty issledovanii, gipotezy ["Shaman's Chum" of the Evenks: The history of Discovery, Research Results, Hypotheses]. In Etnosy $i$ etnicheskie protsessy [Ethnoses and Ethnic Processes], edited by V.A. Popov, 107-118. Moscow: Nauka; Vostochnaia literatura. 